\title{
Antimicrobial Peptide Genes Present in Indigenous Isolates of Bacillus spp. Exhibiting Antimicrobical Properties
}

\author{
Tamalika Sarangi $^{1 *}$, S. Ramakrishnan ${ }^{1}$ and S. Nakkeeran ${ }^{2}$ \\ ${ }^{1}$ Department of Nematology, ${ }^{2}$ Department of Plant Pathology, Centre for Plant Protection \\ Studies, Tamil Nadu Agricultural University, Coimbatore - 641003, India \\ *Corresponding author
}

A B S T R A C T

\begin{tabular}{|c|c|}
\hline Keywords & bial peptide genes \\
\hline $\begin{array}{l}\text { Bacillus spp, } \\
\text { Polymerase } \\
\text { Chain Reaction, } \\
\text { Antimicrobial } \\
\text { peptide genes, } \\
\text { Zwittermycin, } \\
\text { Bacilysin bacD, } \\
\text { Bacilysin bacAB, } \\
\text { Fengycin CAE. }\end{array}$ & $\begin{array}{l}\text { (AMPs) in ten different indigenous isolates of Bacillus spp. proved to be } \\
\text { effective against } M \text {. incognita, Fusarium oxysporum f.sp.lycopersici and } \\
\text { their disease complex. The study revealed the presence of iturin A, iturin C, } \\
\text { iturin D, surfactin, bacilomycin D, fengycin D, zwitermycin, bacillomycin } \\
\text { bac D, bacilysin bcc AB and fengycin CAE in the above isolates of } \\
\text { Bacillus spp. Among the ten different AMPs, the iturin A gene was found } \\
\text { to present in all the ten isolates of Bacillus spp. Of all indigenous isolates }\end{array}$ \\
\hline Article Info & \\
\hline $\begin{array}{l}\text { Accepted: } \\
\text { 17 June } 2017 \\
\text { Available Online: } \\
10 \text { August } 2017\end{array}$ & $\begin{array}{l}\text { with seven genes, B. licheniformis and B. Cereus (TSB 3, CLB2 and } \\
\text { TSB4D) with six genes, B. weihenstephanensis (CLB3) and B. subtilis } \\
\text { (TLBRE1) with four genes and B. subtilis (TSB5) with three genes. }\end{array}$ \\
\hline
\end{tabular}

Introduction

Bacillus spp. is well known for its antimicrobial properties. The members of Bacillus spp., produce a wide array of molecules of diverse function. For example $B$. subtilis, has 4-5 per cent of its genome devoted to antibiotic synthesis and has the potential to produce more than two dozen structurally diverse antimicrobial peptides (AMP). The diverse antibiotics produced by Bacillus spp. includes iturin, surfactin, fengycin, bacillomycin, zwittermicin, bacilysin, mersacidin, ericin, subtilin etc with broad spectrum action and it is reported to vary from species to species. As evidenced by genome sequencing, bacteria dedicate up to 20 per cent of their genome to the biosynthesis of secondary metabolites underscoring the importance of these small molecules to the fitness of the organism in its native environment.

In this regard the antimicrobial peptides of Bacillus spp. specifically play a vital role in protecting plants against diseases and pests. Tamalika Sarangi (2014) collected ten indigenous isolates of Bacillus spp. 
experimented for their biocontrol potential and proved to be effective against $M$. incognita and Fusarium oxysporum f.sp.lycopersici.

Hence the present study is programmed to detect the AMPs genes present in indigenous isolates of Bacillus spp. responsible for their broad spectrum action.

\section{Materials and Methods}

\section{Isolation of genomic DNA}

The genomic DNA of all endophytic isolates were isolated using the standard protocol of Cetyl Trimethyl Ammonium Bromide (CTAB) method proposed by Knapp and Chandlee (1996) with slight modifications made by Melody (1997). The actively grown above bacterial culture of $25 \mathrm{ml}$ broth was taken in a centrifuge tube and centrifuged at $6,000 \mathrm{rpm}$ for $5 \mathrm{~min}$ at $4^{\circ} \mathrm{C}$. After the removal of supernatant, the pellet was suspended in 1 $\mathrm{ml}$ Tris (TE) buffer added with $0.5 \mathrm{ml}$ of 1butanol, vortexed well to mix with the cells in order to remove extracellular materials and centrifuged at $5000 \mathrm{rpm}$ for $5 \mathrm{~min}$ at $4^{\circ} \mathrm{C}$. The supernatant was discarded and the pellet was resuspended in $2 \mathrm{ml}$ of $\mathrm{TE}$ buffer and centrifuged at $6,000 \mathrm{rpm}$ at $4^{\circ} \mathrm{C}$ for $5 \mathrm{~min}$ to remove all traces of butanol. The pellet was again re-suspended in $1 \mathrm{ml}$ TE buffer added with $100 \mu \mathrm{l}$ of lysozyme $\left(10 \mathrm{mg} \mathrm{ml}^{-1}\right.$ freshly prepared) and incubated at room temperature for $5 \mathrm{~min}$. After incubation, $100 \mu \mathrm{l}$ of 10 per cent Sodium Dodecyl Sulphate (SDS) and 25 $\mu 1$ of $100 \mu \mathrm{g} \mathrm{ml}^{-1}$ proteinase $\mathrm{K}$ were added, mixed well and incubated at $37^{\circ} \mathrm{C}$ for an hour. To the above mixture $200 \mu \mathrm{l}$ of $5 \mathrm{M} \mathrm{NaCl}$ was added and mixed well. With this $150 \mu \mathrm{l}$ of CTAB solution was added, mixed well and incubated at $65^{\circ} \mathrm{C}$ for $10 \mathrm{~min}$. The mixture was extracted with $1 \mathrm{ml}$ of phenol: chloroform mixture in the ratio of 25:24, mixed well and centrifuged at $6000 \mathrm{rpm}$ for
$15 \min$ at $4^{\circ} \mathrm{C}$. The aqueous layer was transferred carefully to a $2 \mathrm{ml}$ microfuge tube and DNA was precipitated by adding 0.6 volume of ice cold iso-propanol, incubated overnight at $-20^{\circ} \mathrm{C}$. The DNA was pelleted by centrifugation at $12,000 \mathrm{rpm}$ for $15 \mathrm{~min}$ at $4^{\circ} \mathrm{C}$. The pellet was washed with 70 per cent ethanol and dried under vacuum for $10 \mathrm{~min}$ and resuspended in $50 \mu 1$ of TE buffer. One $\mu 1$ DNAse, free RNAse $\left(10 \mathrm{mg} \mathrm{ml}^{-1}\right)$ was also added by swirling and incubated at $37^{\circ} \mathrm{C}$ for $30 \mathrm{~min}$. The isolated DNA was stored at $20^{\circ} \mathrm{C}$ for further use.

\section{Molecular detection of antibiotic genes of Bacillus spp}

\section{Iturin A}

The forward primer ITUD1F (5'GATGCGATCTCCTTGGATGT3') and reverse primer ITUD1R (5'ATCGTCATG TGCTGCTTGAG3') were used for amplification of iturin A gene (647 bp) (Ramarathnam, 2007). The mixture of $20 \mu \mathrm{l}$ contained approximately $50 \eta \mathrm{g}$ of total DNA, $5 \mathrm{mM}$ each dNTPs, 20 pmol of each forward and reverse primer and $0.5 \mathrm{U}$ of Taq DNA polymerase. The PCR amplification was performed in a thermocycler (Eppendorf Master cycler, German) using the conditions of initial denaturation at $94^{\circ} \mathrm{C}$ for $3 \mathrm{~min}, 40$ cycles consisting of $94^{\circ} \mathrm{C}$ for $1 \mathrm{~min}$ (denaturation), $60^{\circ} \mathrm{C}$ for $1 \mathrm{~min}$ (annealing), $72^{\circ} \mathrm{C}$ for $1 \mathrm{~min}$ (primer extension) and final extension at $72^{\circ} \mathrm{C}$ for $10 \mathrm{~min}$.

\section{Iturin $\mathbf{C}$}

The forward primer ITUCF1 (5'CCCCCTCGGTCAAGTGAATA3') and reverse primer ITUCR1 (5'TTGGTTAAG CCCTGATGCTC3') were used for amplification of iturin C gene (594 bp) (Chung et al., 2008). The $20 \mu l$ mixture contained approximately $50 \eta \mathrm{g}$ of total DNA, 
$5 \mathrm{mM}$ each dNTPs, 20 pmol of each forward and reverse primer and $0.5 \mathrm{U}$ of Taq DNA polymerase. The PCR amplification was performed as above in a thermocycler (Eppendorf Master cycler, German) using the conditions of initial denaturation at $95^{\circ} \mathrm{C}$ for $15 \mathrm{~min}, 40$ cycles consisting of $95^{\circ} \mathrm{C}$ for 1 min (denaturation), $55^{\circ} \mathrm{C}$ for $1 \mathrm{~min}$ (annealing), $72^{\circ} \mathrm{C}$ for $1.5 \mathrm{~min}$ (primer extension) and final extension at $72^{\circ} \mathrm{C}$ for 7 $\min$.

\section{Iturin D}

The forward primer ITUD-F1 (5'TTGAAYGTCAGYGCSCCTTT3') and reverse primer ITUD-R1 (5'TGCGMAAATAATGGSGTCGT3') were used for amplification of iturin D gene (482 bp) (Chung et al., 2008). The $20 \mu \mathrm{l}$ mixture contained approximately $50 \eta \mathrm{g}$ of total DNA, $5 \mathrm{mM}$ each dNTPs, 20 pmol of each forward and reverse primer and $0.5 \mathrm{U}$ of Taq DNA polymerase. The PCR amplification was performed in a thermocycler (Eppendorf Master cycler, German) using the conditions of initial denaturation at $95^{\circ} \mathrm{C}$ for $15 \mathrm{~min}, 40$ cycles consisting of $94^{\circ} \mathrm{C}$ for $1 \mathrm{~min}$ (denaturation), $57^{\circ} \mathrm{C}$ for $1 \mathrm{~min}$ (annealing), $72^{\circ} \mathrm{C}$ for $1.5 \mathrm{~min}$ (primer extension) and final extension at $72^{\circ} \mathrm{C}$ for $10 \mathrm{~min}$.

\section{Surfactin}

The forward primer SUR3F (5'ACAGTATGGAGGCATGGTC3') and reverse primer SUR3R (5'TTCCGCC ACTTTTTCAGTTT3') were used for amplification of surfactin gene (441 bp) (Ramarathnam, 2007). The $40 \quad \mu 1 \quad$ PCR reaction mixture contained DNA template 50 $\eta \mathrm{g}, 1 \mathrm{X}$ Taq buffer, $0.2 \mathrm{mM}$ of each of dNTP mixture, $1 \mu \mathrm{M}$ of each primers, $1.5 \mathrm{mM}$ $\mathrm{MgCl}_{2}$ and $2 \mathrm{U}$ of $T a q$ DNA polymerase. The PCR amplification was performed in a thermocycler (Eppendorf Master cycler, German) using the conditions of initial denaturation at $94^{\circ} \mathrm{C}$ for $3 \mathrm{~min}, 40$ cycles consisting of $94^{\circ} \mathrm{C}$ for $1 \mathrm{~min}$ (denaturation), $57^{\circ} \mathrm{C}$ for 1 min (annealing), $72^{\circ} \mathrm{C}$ for $1 \mathrm{~min}$ (primer extension) and final extension at $72^{\circ} \mathrm{C}$ for $10 \mathrm{~min}$.

\section{Bacillomycin D}

The forward primer BACC1F (5'GAAGGACACGGCAGAGAGTC3') and reverse primer BACC1 $\mathrm{R}$ (5'CGCTGATGACTGTTCATGCT 3') were used for amplification of bacillomycin $\mathrm{D}$ gene (875 bp) (Athukorala et al., 2009). The $20 \mu \mathrm{l}$ mixture contained approximately $50 \mathrm{\eta g}$ of total DNA, $5 \mathrm{mM}$ each dNTPs, 20 pmol of each forward primer and reverse primer and $0.5 \mathrm{U}$ of Taq DNA polymerase. The PCR amplification was performed in a thermocycler (Eppendorf Master cycler, German) using the conditions of initial denaturation at $94^{\circ} \mathrm{C}$ for $3 \mathrm{~min}, 40$ cycles consisting of $94{ }^{\circ} \mathrm{C}$ for $1 \mathrm{~min}$ (denaturation), $59^{\circ} \mathrm{C}$ for $1 \mathrm{~min}$ (annealing), $72^{\circ} \mathrm{C}$ for $1 \mathrm{~min}$ (primer extension) and final extension at $72^{\circ} \mathrm{C}$ for $10 \mathrm{~min}$.

\section{Fengycin D}

The forward primer FEND1F (5'TTTGGC AGCAGGAGAAGTTT3') and reverse primer FEND1 R (5'GCTGTCCGTT CTGCTTTTTC3') were used for amplification of fengycin gene (964 bp) (Athukorala et al., 2009). The $20 \mu 1$ mixture contained approximately $50 \mathrm{\eta g}$ of total DNA, $5 \mathrm{mM}$ each dNTPs, 20 pmol of each forward primer and reverse primer and $0.5 \mathrm{U}$ of $T a q$ DNA polymerase. The PCR amplification was performed in a thermocycler (Eppendorf Master cycler, German) using the conditions of initial denaturation at $94^{\circ} \mathrm{C}$ for $3 \mathrm{~min}, 40$ cycles consisting of $94^{\circ} \mathrm{C}$ for $1 \mathrm{~min}$ (denaturation), $60^{\circ} \mathrm{C}$ for $1 \mathrm{~min}$ (annealing), $72^{\circ} \mathrm{C}$ for $1 \mathrm{~min}$ (primer extension) and final extension at $72^{\circ} \mathrm{C}$ for $10 \mathrm{~min}$. 


\section{Zwittermycin}

The forward primer ZWT1F (5'TTTGGC AGCAGGAGAAGTTT3') and reverse primer ZWT1 R (5'GCTGTCCGTTC TGCTTTTTC3') were used for amplification of Zwittermycin gene (779 bp) (Athukorala et al., 2009). The $20 \mu \mathrm{l}$ mixture contained approximately $50 \eta \mathrm{g}$ of total DNA, $5 \mathrm{mM}$ each dNTPs, 20 pmol of each forward and reverse primer and $0.5 \mathrm{U}$ of Taq DNA polymerase.The PCR amplification was performed in a thermocycler (Eppendorf Master cycler, German) using the conditions of initial denaturation at $94^{\circ} \mathrm{C}$ for $3 \mathrm{~min}, 40$ cycles consisting of $94^{\circ} \mathrm{C}$ for $1 \mathrm{~min}$ (denaturation), $57^{\circ} \mathrm{C}$ for $1 \mathrm{~min}$ (annealing), $72^{\circ} \mathrm{C}$ for $1 \mathrm{~min}$ (primer extension) and final extension at $72^{\circ} \mathrm{C}$ for $10 \mathrm{~min}$.

\section{Bacilysin bacD}

The forward primer BACDF1 (5'AAAAAC AGTATTGGTYATCGCTGA3') and reverse primer BACDR1 (5'CCATGATGCC TTCKATRCTGAT3') were used for amplification of Bacilysin bacD gene (749bp) (Chung et al., 2008). The $20 \mu l$ mixture contained approximately 50 $\mathrm{\eta g}$ of total DNA, $5 \mathrm{mM}$ each dNTPs, 20 pmol of each forward primer and reverse primer and $0.5 \mathrm{U}$ of $\mathrm{Taq}$ DNA polymerase. The PCR amplification was performed in a thermocycler (Eppendorf Master cycler, German) using the conditions of initial denaturation at $95^{\circ} \mathrm{C}$ for $15 \mathrm{~min}, 40$ cycles consisting of $95^{\circ} \mathrm{C}$ for $1 \mathrm{~min}$ (denaturation), $52^{\circ} \mathrm{C}$ for $1 \mathrm{~min}$ (annealing), $72^{\circ} \mathrm{C}$ for $1.5 \mathrm{~min}$ (primer extension) and final extension at $72^{\circ} \mathrm{C}$ for $7 \mathrm{~min}$.

\section{Bacilysin bacAB}

The forward primer BACAB-F1 (5'CTTCTCCAAGGGGTGAACAG3') and reverse primer BACAB-R1 (5'TGTAGG TTTCACCGGCTTTC3') were used for amplification of Bacilysin bacAB gene (815bp) (Chung et al., 2008). The $20 \mu 1$ mixture contained approximately $50 \mathrm{\eta g}$ of total DNA, $5 \mathrm{mM}$ each dNTPs, 20 pmol of each forward and reverse primer and $0.5 \mathrm{U}$ of Taq DNA polymerase. The PCR amplification was performed in a thermocycler (Eppendorf Master cycler, German) using the conditions of initial denaturation at $95^{\circ} \mathrm{C}$ for $15 \mathrm{~min}, 40$ cycles consisting of $95^{\circ} \mathrm{C}$ for $1 \mathrm{~min}$ (denaturation), $50^{\circ} \mathrm{C}$ for 1 min (annealing), $72^{\circ} \mathrm{C}$ for $1.5 \mathrm{~min}$ (primer extension) and final extension at $72^{\circ} \mathrm{C}$ for $7 \mathrm{~min}$.

\section{Fengycin CAE}

The forward primer FENCEA F1(5'CCCATCCGACYGTAGAAG3') and reverse primer FENCEA R1 (5'GTGTAAGC RGCAAGYAGCAC3') were used for amplification of Fengycin CAE gene (820 bp) (Chung et al., 2008). The $20 \mu l$ mixture contained approximately 50 ๆg of total DNA, $5 \mathrm{mM}$ each dNTPs, 20 pmol of each forward and reverse primer and $0.5 \mathrm{U}$ of Taq DNA polymerase. The PCR amplification was performed in a thermocycler (Eppendorf Master cycler, German) using the conditions of initial denaturation at $95^{\circ} \mathrm{C}$ for $15 \mathrm{~min}, 40$ cycles consisting of $95^{\circ} \mathrm{C}$ for $1 \mathrm{~min}$ (denaturation), $55^{\circ} \mathrm{C}$ for $1 \mathrm{~min}$ (annealing), $72^{\circ} \mathrm{C}$ for $1.5 \mathrm{~min}$ (primer extension) and final extension at $72^{\circ} \mathrm{C}$ for $7 \mathrm{~min}$

\section{Results and Discussion}

The isolated ten endophytic bacteria as Bacillus spp. were subjected to PCR for the detection of antibiotic biosynthetic genes and the result of the study is furnished in table 1 .

\section{Iturin A}

The specific primers meant for iturin A gene bind with the genomic DNA and amplified to form an amplicon size of $647 \mathrm{bp}$. Therefore this positive reaction of PCR revealed that all 
the ten species / isolates viz. $B$. weihenstephanensis, B. cereus, B. subtilis, B. licheniformis, $B$. thuringiensis and $B$. tequilensis possessing the iturin A gene.

\section{Iturin C}

In contrast, only five isolates of Bacillus spp. viz. B. weihenstephanensis (CLB3), B. subtilis (TLBRE1), B. thuringiensis (TLBRE2) and $B$. cereus (CLB2 and CLB2D) were found to have iturin $\mathrm{C}$ gene since the test undertaken for the detection of antibiotic biosynthetic gene showed positive reaction of binding of specific primers with the genomic DNA and amplifying to form an amplicon size of 594 bp which is characteristic for the detection of iturin $\mathrm{C}$ gene.

\section{Iturin D}

In the test for the detection of iturin D gene it is observed that six native isolates viz. $B$. subtilis (TSB5), B. weihenstephanensis (CLB3), B. tequilensis (TLB2), $B$. thuringiensis (TLBRE2) and $B$. cereus (TSB4D and CLB2) were found in possession of iturin $\mathrm{D}$ gene as the test is positive by binding of specific primers with the genomic DNA and amplifying to form an amplicon size of 482 bp which is characteristic of the iturin $\mathrm{D}$ gene.

\section{Surfactin}

With regard to the detection of antibiotic biosynthetic gene, the surfactin gene was found to present only in seven isolates viz. $B$. weihenstephanensis (CLB3), B. thuringiensis (TLBRE2), B. subtilis (TLBRE1), B. cereus (CLB2, TSB4D and CLB2D) and $B$. tequilensis (TLB2) through positive reaction showing the binding of specific primers meant for surfactin with genomic DNA and amplifying to form an amplicon size of 441 bp.

\section{Bacillomycin D}

Among ten isolates of Bacillus spp. subjected for the detection of Bacillomycin $D$ gene except two native species / isolates of $B$. weihenstephanensis (TSB4) and B. cereus (CLB2) others showed the possession of the above antibiotic biosynthetic gene. It was confirmed through the positive reaction of binding of specific primers with genomic DNA and amplifying with the fragment size of $875 \mathrm{bp}$. with the remaining isolates of Bacillus spp.

\section{Zwittermycin}

The positive reaction of binding of specific primers with the genomic DNA and amplifying to form an amplicon size of 779 bp was noticed with only one isolate TLB2 of B. tequilensis.

\section{Bacilysin bac D}

The test performed for the detection of bacilysin bac $\mathrm{D}$ gene was found to be positive with the four native isolates viz. $B$. licheniformis (TSB3), B. tequilensis (TLB2), $B$. thuringiensis (TLBRE2) and B. cereus (CLB2D) based on binding of specific primers with the genomic DNA and amplifying to form an amplicon size of 749 bp which is characteristic of bacilysine bac D gene.

\section{Bacilysin bac AB}

Among the ten native isolates of Bacillus spp. tested for the presence of bacilysin bac $A B$ gene, only five isolates viz. B. licheniformis (TSB3), B. weihenstephanensis (TSB4), B. tequilensis (TLB2), $B$. thuringiensis (TLBRE2) and $B$. cereus (CLB2D) were found to be positive through binding of specific primers with the genomic DNA and 
amplifying to form an amplicon size of 815 bp due to the possession of bacilysine bac AB gene.

\section{Fengycin CAE}

Six native isolates viz. $B$. licheniformis (TSB3), B. weihenstephanensis (TSB4), $B$. thuringiensis (TLBRE2) and $B$. cereus (CLB2, CLB2D and TSB4D) were found to be positive in the test performed for the detection of the above gene. In this test the positive reaction was confirmed through binding of specific primers with the genomic DNA and amplifying to form an amplicon size of $820 \mathrm{bp}$ which is characteristics to denote the presence of fengycin CAE gene. In the above test undertaken for the detection of antibiotic biosynthetic genes, the iturin A gene was found to be present in all the ten isolates of Bacillus spp. Although all the above ten native isolates of Bacillus spp. were found in possession of one or more genes, the isolates of Bacillus spp. viz., B. thuringiensis (TLBRE2), B. cereus (CLB2D) were found to possess higher number of eight antibiotic biosynthetic genes. It was followed by $B$. tequilensis (TLB2) with seven genes, $B$. licheniformis and B. cereus (TSB3, CLB2 and TSB4D) with six genes; $B$. weihenstephanensis (CLB3) with five genes; $B$. weihenstephanensis (TSB4) and B. subtilis (TLBRE1) with four genes and B. subtilis (TSB5) with three genes. The antimicrobial peptides are potent, broad spectrum antibiotics and they are being currently used as novel therapeutic agents. Antimicrobial peptides have been demonstrated to kill pathogens, envelop pathogenic bacteria, virus, fungi and nematodes. The AMPs produced by Bacillus spp. have been implicated in the biocontrol of several plant pathogens causing aerial, soil and postharvest diseases and in the promotion of plant growth. In addition to lipopeptides, other peptidic compounds such as bacilysin, a dipeptide described in $B$. amyloliquefaciens FZB42 and subtilin, a lantibiotic described in $B$. subtilis are active in the biocontrol of plant pathogens. The biocontrol ability of several strains of Bacillus in the management of plant pathogens has been linked to the presence of the AMP biosynthetic genes viz. bmyB, fenD, ituC, srfAA, and srfAB. According to Mora et al., (2011) the simultaneous production of different AMPs were important for the antagonistic activity of Bacillus spp.

In addition, the genome analysis of the $B$. amyloliquefaciens FZB 42 revealed the presence of several AMP genes rather than one or two genes responsible for broad spectrum of action against plant pathogens as indicated by Chen et al., (2009). Similar genes have been reported in the commercialized strains of $B$. subtilis viz. GB03, QST713 and MBI 600 which are presently available commercially in the USA market (Arguelles et al., 2009). Besides, srrfAA, bmyB, bacA, and fend genes dominant in plant environment and reinforces the competitive role of surfactin, bacillomycin, fengycin and bacilysin in conferring strain fitness in natural environment (Mora et al., 2011). Hence, an understanding of the role of AMPs in the ecological fitness of the plants is imperative.

Antibiotic production by the bacterial endophytes plays a major role in plant disease suppression. For example the endophytic Bacillus spp. produces more than 24 antibacterial (Ono and Kimura 1991 and SiloSuh et al., 1994), antifungal (Nishikiori et al., 1986 and Maget- Dana and Peypoux, 1994), antinematicidal (Broderick et al., 2003) and antiviral and antimycoplasmal (Vollenbroich et al., 1997) compounds with diverse structures and function belonging to peptides. 
Table.1 Identification of antimicrobial peptide genes associated with different native Bacillus spp.

\begin{tabular}{|c|c|c|c|c|c|c|c|c|c|c|c|}
\hline \multirow[b]{2}{*}{ S.No. } & \multirow{2}{*}{$\begin{array}{l}\text { Antimicrobial } \\
\text { peptide genes }\end{array}$} & \multicolumn{10}{|c|}{ Bacillus spp. } \\
\hline & & $\begin{array}{c}B . s \\
\text { (TSB5) } \\
\end{array}$ & $\begin{array}{l}\text { B. } l \\
\text { (TSB3) }\end{array}$ & $\begin{array}{r}B . w \\
\text { (TSB4) }\end{array}$ & $\begin{array}{l}\text { B. } w \\
\text { (CLB3) }\end{array}$ & $\begin{array}{c}B . t \\
\text { (TLB2) } \\
\end{array}$ & $\begin{array}{c}\text { B. th } \\
\text { (TLBRE2) } \\
\end{array}$ & $\begin{array}{r}B . s \\
\text { (TLBRE1) } \\
\end{array}$ & $\begin{array}{c}\text { B. } c \\
\text { (CLB2) }\end{array}$ & $\begin{array}{c}B . c \\
(\text { TSB4D) } \\
\end{array}$ & $\begin{array}{c}B \cdot c \\
(\text { CLB2D) }\end{array}$ \\
\hline 1 & Iturin $\mathrm{A}$ & + & + & + & + & + & + & + & + & + & + \\
\hline 2 & Iturin $\mathrm{C}$ & - & - & - & + & - & + & + & + & - & + \\
\hline 3 & Iturin D & + & - & - & + & + & + & - & + & + & - \\
\hline 4 & Surfactin & - & - & - & + & + & + & + & + & + & + \\
\hline 5 & Bacillomycin D & + & + & - & + & + & + & + & - & + & + \\
\hline 6 & Fengycin D & - & + & + & - & - & - & - & + & + & + \\
\hline 7 & Zwittermycin & - & - & - & - & + & - & - & - & - & - \\
\hline 8 & Bacilysin bac D & - & + & - & - & + & + & - & - & - & + \\
\hline 9 & Bacilysin bac AB & - & + & + & - & + & + & - & - & + & + \\
\hline 10 & Fengycin CEA & - & + & + & - & - & + & - & + & - & + \\
\hline
\end{tabular}

Note: '+': Positive and '-': Negative reaction

\begin{tabular}{|l|l|}
\hline B. $s$. & B. subtilis \\
\hline B. $l$. & B. licheniformis \\
\hline B. $w$. & B. weihenstephanensis \\
\hline B. $c$. & B. cereus \\
\hline B. $t$. & B. tequilensis \\
\hline B. th. & B. thuringiensis \\
\hline
\end{tabular}


Montesinos, (2007) reported that this type of short sequence peptides with generally fewer than 50 amino acid residues present in living system acting as first line of defence in plants and animals. Hence it is considered that the detection of antibiotic production by Bacillus spp. is a prime need to determine the effectiveness of the bacterial isolates as it serves as an index to decide the ability of an individual organism to control plant diseases.

Therefore in the present work an attempt has been made to detect the production of antibiotic compounds in the above ten isolates of Bacillus spp. The present study indicated the presence of iturin $A$ gene in all the ten isolates of Bacillus spp. Whereas the presence of other genes viz. iturin $\mathrm{C}$ gene in five isolates of $B$. weihenstephanensis (CLB3), $B$. thuringiensis (TLBRE2), B. subtilis (TLBRE1) and $B$. cereus (CLB2D and CLB2); iturin D gene in six isolates of $B$. subtilis (TSB5), B. weihenstephanensis (CLB3), B. tequilensis (TLB2), $B$. thuringiensis (TLBRE2) and $B$. cereus (TSB4D and CLB2); surfactin gene in seven isolates of $B$. weihenstephanensis (CLB3), $B$. tequilensis (TLB2); B. thuringiensis (TLBRE2); B. subtilis (TLBRE1), B. cereus (TSB4D,CLB2D and CLB2) and bacillomycin $\mathrm{D}$ gene in eight isolates of $B$. licheniformis (TSB3), B. weihenstephanensis (CLB3), B. tequilensis (TLB2), $B$. thuringiensis (TLBRE2), B. subtilis (TLBRE1 and TSB5), B. cereus (CLB2D and TSB4D); fengycin $\mathrm{D}$ gene in five isolates of $B$. licheniformis (TSB3), B. weihenstephanensis (TSB4), B. cereus (CLB2, CLB2D and TSB4D); zwittermycin gene in one isolate of B. tequilensis (TLB2); bacilysin bac D gene in four isolates of $B$. licheniformis (TSB3), $B$. tequilensis (TLB2), B. thuringiensis (TLBRE2) and B. cereus (CLB2D); bacilysin bac $A B$ gene found only in four isolates viz. B. licheniformis (TSB3), $B$. weihenstephanensis (TSB4), B. tequilensis
(TLB2), B. thuringiensis (TLBRE2) and $B$. cereus (CLB2D and CLB2D); fengycin CAE gene in five isolates of $B$. licheniformis (TSB3), B. weihenstephanensis (TSB4), $B$. thuringiensis (TLBRE2), B. cerus (CLB2, CLB2D) is noticed with the tested ten isolates of Bacillus spp. in the present study. The available literature quoting the presence of different antibiotic biosynthetic genes viz. iturin A, iturin C, iturin D (Montesinos, 2007 and Assie et al., 2002); surfactin, fengycin (Mora et al., 2011) in B. amyloliquifaciens, bacilysin $\mathrm{D}$ and $\mathrm{AB}$ in $B$. subtilis (Montesinos 2007), bacilomycine D (Ramanatham et al., 2007) in B. subtilis and B. amyloliquifaciens is in conformity with the findings of the present study. Ongena et al., (2005) reported cyclic lipopeptides of the surfactin, iturin and fengycin families from Bacillus, impart successful biocontrol activity by direct suppression of phytopathogens and reinforcing of the potentiality of host plants through stimulating induced systemic resistance phenomenon.

\section{References}

Arguellesarias, A., M. Ongena, B. Halimi, Y. Lara, A. Brans and B. Joris. 2009. Bacillus amyloliquefaciens GA1 as a source of potent antibiotics and other secondary metabolites for biocontrol of plant pathogens. Appl. Environ. Microbiol., 60: 2023-2030.

Assie, L.K., M. Deleu, L. Arnaud, M. Paquot, P. Thonart, C. Gaspar and E. Haubruge. 2002. Insecticide activity of surfactins and iturins from a biopesticide Bacillus subtilis Cohn (S499 strain). Meded. Rijksuniv. Gent. Fak. Landbouwkd. Toegep. Biol. Wet., 3: 647- 655.

Athukorala, Y., W.K. Jung, T. Vasanthan and Y.J. Jeon. 2006. An anti-coagulative polysaccharide from an enzymatic hydrolysate of Ecklonia cava. Carbohydr. Polym., 66: 184-191.

Broderick, N.A., R.M. Goodman, J. 
Handelsman and K.F. Raffa. 2003. Effect of host diet and insect source on synergy of gypsy moth (Lepidoptera: Lymantriidae) mortality to Bacillus thuringiensis subsp. kurstaki by zwittermicin A. Environ. Entomol., 32(2): 387-391.

Chen X.H., R. Scholz, M. Borriss, H. Junge, G. Mogel, S. Kunz and R. Borriss. 2009. Difficidin and bacilysin produced by plant-associated Bacillus amyloliquefaciens are efficient in controlling fire blight disease. J. Biotech., 140:38-44.

Chung, S., H. Kong, J.S. Buyer, D.K. Lakshman, J. Lydon, and S.D. Kim. 2008. Isolation and partial characterization of Bacillus subtilis ME488 for suppression of soilborne pathogens of cucumber and pepper. Appl. Microbiol. Biotechnol., 80(1): 115-23.

Maget-Dana, R., and F. Peypoux. 1994. Iturins, a special class of spore-forming lipopeptides: Biological control of plant diseases. Phytopathol., 94: 1267-1271.

Montesinos, E. 2007. Antimicrobial peptides and plant disease control. FEMS Microbiol. Lett., 270: 1-11.

Mora, I., J. Cabrefiga and E. Montesinos. 2011. Antimicrobial peptide genes in Bacillus strains from plant environments. Int. Microbiol., 14: 213-223.

Nishikori, T., H. Naganawa, Y. Muraoka, T. Aoyagi and H. Umezawa. 1986. Plispastins; new inhibitors of phospholopase A2, produced by Bacillus cereus BMG302-fF67.III. Structural elucidation of plispastins. J. Antibiot., 39: 755-761.
Ongena, M., P. Jacques, Y. Toure, J. Destain, A. Jabrane, and P. Thonart. 2005. Involvement of fengycin-type lipopeptides in the multifaceted biocontrol potential of Bacillus subtilis. Appl. Microbiol. Biotechnol., 69: 29-38.

Ono, M. and N. Kimura. 1991. Antifungal peptides produced by Bacillus subtilis for the biological control of aflatoxin contamination. Proceedings of the Japanese Association of Mycotoxicology, 34: 23-28.

Ramanrathnam. 2007. Molecular and biochemical detection of fengycin and bacillomycin D producing Bacillus spp., antagonistic to fungal pathogens of canola and wheat. Can. J. Microbiol., 53: 901911.

Silo-suh, L.A., B.J. Lethbridge, S.J. Raffel, H. He, J. Clardy and J. Handelsman. 1994. Meloidogyne incognita infection and tomato plant growth. J. ISSAAS., 19(2): 68-74.

Tamalika Sarangi. 2014. Utilization of antinemic or antimicrobial peptide genes associated with Bacillus spp. in the management of root knot nematode Meloidogyne incognita (Kofoid and White, 1919) Chitwood, 1949 on tomato (Solanum lycopersicum Mill). Ph.D dissertation, Tamil Nadu Agricultural University, Coimbatore, Tamil Nadu, India, P. 371.

Vollenbroich, D., G. Pauli, M. Ozel, and J. Vater. 1997. Antimycoplasma properties and application in cell culture of surfactin, a lipopeptide antibiotic from Bacillus subtilis. Appl. Environ. Microbiol., 63: 44-49.

\section{How to cite this article:}

Tamalika Sarangi, S. Ramakrishnan and S. Nakkeeran. 2017. Antimicrobial Peptide Genes Present in Indigenous Isolates of Bacillus Spp. Exhibiting Antimicrobical Properties. Int.J.Curr.Microbiol.App.Sci. 6(8): 1361-1369. doi: https://doi.org/10.20546/ijcmas.2017.608.166 